\title{
Analysis of tomato gene promoters activated in syncytia induced in tomato and potato hairy roots by Globodera rostochiensis
}

\author{
A. Wiśniewska $\cdot$ J. Dąbrowska-Bronk $\cdot$ K. Szafrański $\cdot$ S. Fudali $\cdot$ \\ M. Święcicka $\cdot$ M. Czarny $\cdot$ A. Wilkowska $\cdot$ K. Morgiewicz $\cdot$ J. Matusiak \\ M. Sobczak $\cdot$ M. Filipecki
}

Received: 20 June 2012/Accepted: 5 October 2012/Published online: 6 November 2012

(C) The Author(s) 2012. This article is published with open access at Springerlink.com

\begin{abstract}
The potato cyst nematode (Globodera rostochiensis) induces feeding sites (syncytia) in tomato and potato roots. In a previous study, 135 tomato genes up-regulated during G. rostochiensis migration and syncytium development were identified. Five genes (CYP97A29, DFR, FLS, NIK and
\end{abstract}

Electronic supplementary material The online version of this article (doi:10.1007/s11248-012-9665-4) contains supplementary material, which is available to authorized users.

A. Wiśniewska $(\bowtie) \cdot$ K. Szafrański · A. Wilkowska · K. Morgiewicz · J. Matusiak

Department of Plant Physiology, Faculty of Agriculture and Biology, Warsaw University of Life Sciences (SGGW), Nowoursynowska 159, 02-776 Warsaw, Poland e-mail: anita_wisniewska@sggw.pl

J. Dąbrowska-Bronk · M. Święcicka ·

M. Czarny · M. Filipecki

Department of Plant Genetics, Breeding and

Biotechnology, Faculty of Horticulture and Landscape

Architecture, Warsaw University of Life Sciences

(SGGW), Nowoursynowska 159, 02-776 Warsaw, Poland

Present Address:

K. Szafrański

Systématique, Adaptation, Evolution (SAE), Université

Pierre et Marie Curie, UMR 7138 (UPMC CNRS IRD

MNHN), bâtiment A, 7, quai St. Bernard, 75005 Paris,

France

\section{S. Fudali · M. Sobczak}

Department of Botany, Faculty of Agriculture and

Biology, Warsaw University of Life Sciences (SGGW),

Nowoursynowska 159, 02-776 Warsaw, Poland
$P M E I)$ were chosen for further study to examine their roles in plant-nematode interactions. The promoters of these genes were isolated and potential cis regulatory elements in their sequences were characterized using bioinformatics tools. Promoter fusions with the $\beta$-glucuronidase gene were constructed and introduced into tomato and potato genomes via transformation with Agrobacterium rhizogenes to produce hairy roots. The analysed promoters displayed different activity patterns in nematode-infected and uninfected transgenic hairy roots.

Keywords Gene promoter - Globodera rostochiensis $\cdot$ Hairy roots $\cdot$ Nematode $\cdot$ Tomato . Syncytium

\section{Abbreviations \\ ITE Independent transformation event \\ NFS Nematode feeding site}

\section{Introduction}

Sedentary root endoparasitic (root-knot and cyst forming) nematodes can have a serious negative impact on crop production. Both types of nematode induce specialized nematode feeding sites (NFS) and their life cycles and parasitic habits are well characterized (Williamson and Hussey 1996; Sobczak and 
Golinowski 2011). The parasitic second-stage juvenile migrates through the cortex towards the vascular cylinder. It then selects an initial syncytial cell among inner cortical cells (Globodera sp.) or cambial cells (Meloidogyne sp. and Heterodera sp.) from which to form the NFS. The properly formed feeding site provides each juvenile with permanent nutrient delivery and allows them to progress to maturity, i.e. sedentary egg-laying females or motile males.

Traditional methods of plant protection against nematodes (fallow periods, inundation, crop rotation, and nematode repelling soil treatments) are costly and not sufficiently effective. On the other hand, antinematode chemicals can cause environmental damage. Biological control methods (e.g. nematopathogenic fungi) are still under development (Yan et al. 2011). Similarly, biotechnological methods focused on transgenic plants and classical breeding methods based on natural host resistance genes have yet to fulfil their potential. The resistance mediated by tomato $\mathrm{HI}$ (Bakker et al. 2004) is effective only in the case of the Ro1 pathotype of Globodera rostochiensis and the resistance against Globodera pallida provided by the Gpa2 gene (van der Vossen et al. 2000) has been overcome by this pathogen (Gommers and Bakker 1993). The tomato Hero gene provides different levels of resistance to all pathotypes of $G$. rostochiensis and $G$. pallida (Ernst et al. 2002). The introduction of Hero into a susceptible tomato cultivar caused an appreciable decrease of the number of developing nematode females, but no resistant reaction was observed in transgenic potato plants carrying the HeroA gene (Sobczak et al. 2005). The potato Grol-4 and Hsl pro-1 genes, which provide resistance against the Ro1 pathotype of G. rostochiensis (Paal et al. 2004) and Heterodera schachtii (Cai et al. 1997), respectively, were not effective when transferred alone into different plant species. When transferred to tomato, the $M i$ gene originating from Solanum peruvianum conferred resistance to root-knot nematodes Meloidogyne incognita, Meloidogyne javanica and Meloidogyne arenaria, but not to Meloidogyne hapla (Ammati et al. 1985; Hadisoeganda and Sasser 1982, Kaloshian et al. 1996). Resistance controlled by this gene was found to be unstable at higher temperatures (Ammati et al. 1986; Dropkin 1969). Milligan et al. (1998) confirmed that one of two candidate genes in the $M i$ locus $(M i-1.2)$ is responsible for tomato resistance to three Meloidogyne species.
One of the most promising biotechnological approaches to the production of nematode-resistant plants is the specific localization of anti-nematode products within a NFS. Several strategies may be used to enhance plant resistance to these pathogens, e.g. dsRNA targeted against plant or nematode genes, or the expression of anti-nematode products. The application of this type of approach using constitutive promoters can produce unintended effects in uninfected plant organs. Therefore, precise spatial and temporal control of transgene expression is very important and this can be achieved by carefully selecting the promoter regions used in gene constructs. When attempting to combat plant nematode parasitism, transgene expression should be restricted to the inedible roots (e.g. tomato, potato), or even strictly to the NFS, particularly in plant species where the roots are economically important (e.g. beet). To date, there have been no reports of native promoters that are active only in NFS (after nematode attack) and many candidate genes need to be analysed in order to obtain the 'ideal' promoter for this purpose. It may be necessary to isolate and combine cis regulatory elements of various origin to produce an artificial promoter that is strongly activated in NFS.

As no single method can produce solid plant immunity to nematode attack, a combined approach is required, e.g. resistance genes in combination with mechanisms of disturbing the plant-nematode interaction. However, the latter strategy should not disrupt the metabolism of non-infected plant cells. Nematodes have evolved sophisticated strategies for exploiting their host plants based on natural and non-specific plant mechanisms. The modulation of plant cell metabolism by parasitic nematodes is achieved by secretions from nematode glands, which evoke changes in host gene expression and lead to the establishment and maintenance of the NFS (Abad and Williamson 2010). Secreted proteins with different functions, called effectors, can subtly but precisely manipulate plant cell metabolism (Haegeman et al. 2012). Blocking of nematode-induced plant molecular processes promoting nematode development can be achieved by transgene expression targeting these specific mechanisms.

Transformed hairy roots produced by infection of plant tissues with the gram-negative bacterium Agrobacterium rhizogenes have been used in studies on plant-nematode interactions, including plant promoter 
analysis (Hansen et al. 1996; Wang et al. 2007) and gene function analysis (Gal et al. 2006; Huang et al. 2006; Li et al. 2010a; Plovie et al. 2003; Urwin et al. 1995).

We have previously identified 226 tomato genes that show modified expression during G. rostochiensis migration and syncytium development (Swiecicka et al. 2009; unpublished data). For the present study, we selected the genes CYP97A29, DFR, FLS, NIK and $P M E I$ that encode putative proteins with homology to other known proteins related to defense reactions, and that show up-regulation during the first days post infection by G. rostochiensis (Swiecicka, unpublished data). The product of the CYP97A29 gene belongs to a family of P450 monooxygenases, which are involved in the biosynthesis of many different compounds, i.e. flavonoids, phenolic esters, coumarins, glucosinolates, as well as antioxidants and defence compounds (Kahn and Durst 2000). Moreover, CYP97A29 encodes carotenoid $\beta$-hydroxylase, which participates in lutein biosynthesis in tomato leaves and fruit (Stigliani et al. 2011). Cytochrome P450 genes from other plant species are known to be involved in defence responses against microbial pathogens, e.g. pepper $\mathrm{CaCYP450A}$ (Hwang and Hwang 2010), Arabidopsis CYP82C2 (Liu et al. 2010) and wheat CYP709C1 (Li et al. 2010b). The DFR, FLS, NIK and PMEI genes encode a putative dihydroflavonol-4-reductase (DFR), flavonol synthase/flavanone 3-hydroxylase (FLS), protein kinase domain-containing protein (NIK-nematode induced kinase protein) and a plant invertase/pectin methylesterase inhibitor domain-containing protein (PMEI), respectively, which have not previously been described in tomato. DFR and FLS are enzymes participating in flavonoid biosynthesis. Flavonoids are plant secondary metabolites involved in plant defences against pathogenic microorganisms, but they also participate in symbiotic plant-microbe interactions (Wasson et al. 2006). These compounds are known to accumulate in plant tissues in response to nematodes (Hutangura et al. 1999; Jones et al. 2007). PMEs (pectin methylesterases) are produced by pathogenic microorganisms during plant infection and in symbiotic plant-microbe interactions (Lievens et al. 2002). Hewezi et al. (2008) showed that PME3 from Arabidopsis thaliana is a target for the cellulose binding protein (HgCBP) of $H$. schachtii, and this interaction probably facilitates cyst nematode parasitism. PME activity may be regulated by either differential expression or posttranslational control by PME protein inhibitors (PMEIs) (Giovane et al. 2004). The overexpression of two inhibitors, AtPMEI-1 and -2, resulted in a decrease in PME activity and an increase in resistance to fungus Botrytis cinerea in Arabidopsis (Lionetti et al. 2007). Recombinant and purified pepper CaPMEI1 protein exhibited in vitro antifungal activity against three plant pathogenic fungi (Fusarium oxysporum f.sp. matthiole, Alternaria brassicicola and B. cinerea), while CaPMEI1-silenced pepper plants showed enhanced susceptibility to Xanthomonas campestris pv. vesicatoria infection (An et al. 2008). Transgenic Arabidopsis plants overexpressing CaPMEI1 displayed enhanced resistance to Pseudomonas syringae pv. tomato DC3000, but not to Hyaloperonospora parasitica (An et al. 2008). To date there is no clear evidence for the direct involvement of the genes selected for this study (or their orthologues) in plant-nematode interactions.

The aim of this study was to isolate the promoter regions of the aforementioned genes and to analyse their activity in tomato and potato roots, before and during nematode parasitism.

\section{Materials and methods}

Promoter isolation and cloning

Genes were selected from a set of tomato genes that were shown to be up-regulated after G. rostochiensis infection by Swiecicka et al. (2009) (Table S1). The 5' upstream regions of these genes were amplified using a BD Advantage ${ }^{\mathrm{TM}}$ Genomic PCR kit (BD Biosciences Clontech) from adaptor-ligated tomato genomic libraries prepared by the GenomeWalker ${ }^{\mathrm{TM}}$ protocol (BD Bioscences Clontech). Genomic DNA was isolated from frozen tomato leaves using the CTAB method. The quantity and quality of the gDNA were assessed spectrophotometrically and by gel electrophoresis. The gDNA was digested in separate reactions with a panel of four restriction endonucleases cleaving 6-bp recognition sequences to leave a blunt end (DraI, EcoRV, PvuII, StuI). A GenomeWalker adaptor DNA was ligated to the ends of fragments in each digest mixture to produce four adaptor-ligated libraries. Genomic sequences were amplified from these libraries by nested PCR using primers designed to the $5^{\prime}$ ends of the respective cDNAs (Table S1) in combination with adaptor primers (AP1 and AP2). 
The gene-specific primers were designed using the OLIGO program (Primer Analysis Software ver. 6.54, Molecular Biology Insight Inc., USA). The PCR products were cloned in vector pCRII-TOPO (Invitrogen) and sequenced. To identify potential cis-acting regulatory elements, the promoter fragment sequences were analysed with the PLACE program (Higo et al. 1999; http://www.dna.affrc.go.jp/PLACE/signalscan. html). The obtained promoter sequences also contained the $5^{\prime}$ UTR (untranslated region) of the genes.

\section{Reporter gene construct preparation}

To prepare constructs in which the isolated promoters were fused with the $\beta$-glucuronidase ( $g u s A$ ) reporter gene, the fragments were subcloned into a modified pCAMBIA1381Z binary vector (http://www.cambia. org) containing the kanamycin resistance gene (nptII) instead of the hygromycin resistance gene (hpt). To facilitate subcloning, promoter fragments were amplified using primers containing added restriction sites (Table S2), digested with these restriction endonucleases and ligated to the vector that had been cleaved with the same enzymes. The desired constructs were transferred into A. rhizogenes ATCC 15834 by electroporation (MicroPulser, Bio-Rad).

Plant transformation and infection

with $G$. rostochiensis

Tomato (Lycopersicon esculentum Mill. cv. Money Maker) and potato (Solanum tuberosum L. cv. Desiree) plants were used in the study. Tomato and potato hairy roots were obtained as described by Hwang et al. (2000). Cotyledons or hypocotyls were excised from 8- to 10-day-old tomato seedlings and the tips of the former were removed before immersion in A. rhizogenes suspension for $30 \mathrm{~min}$. The cotyledon explants were blotted on sterilized filter paper to remove excess bacteria and then transferred onto solid 1/2 MS medium (Murashige and Skoog 1962) containing $2 \%$ sucrose and $0.8 \%$ agar. Three days later, the cotyledons were transferred onto fresh MS medium containing $75 \mathrm{mg} \mathrm{L} \mathrm{L}^{-1}$ kanamycin and $200 \mathrm{mg} \mathrm{L}^{-1}$ timentin, and left for 7-10 days at $26{ }^{\circ} \mathrm{C}$ in darkness. During this incubation period, hairy roots become visible on the surface of the explants. In the case of potato, stem segments and leaves were used for transformation. As negative controls, explants of both species were also transformed by the wild-type strain of A. rhizogenes or A. rhizogenes carrying the unmodified pCAMBIA1381Z vector (gusA gene lacking a promoter sequence). Hairy roots grew on selective medium in darkness and were tranfered on the fresh medium every 3 weeks as $2-3 \mathrm{~cm}$ root explants.

After 14 days incubation on selective medium, subclonned hairy roots from independent transformation events (ITE) were transferred to fresh antibioticfree MS medium supplemented with $2 \%$ sucrose and $1.5 \%$ agar ( $\mathrm{pH}$ 6.2) (three root explants per Petri dish). After a further 14-21 days, the roots were inoculated with about 200 freshly hatched sterile second-stage juveniles of $G$. rostochiensis Woll. (pathotype Ro1) per Petri dish. The juveniles were obtained from dry cysts as described by Goverse et al. (2000).

\section{GUS activity assay}

Histochemical detection of GUS activity was performed according to the method of Jefferson et al. (1987). The root samples were incubated in $1 \mathrm{mM}$ $\mathrm{X}$-Gluc in $50 \mathrm{mM} \mathrm{NaH}_{2} \mathrm{PO}_{4} \mathrm{pH} 7.2$ at $37{ }^{\circ} \mathrm{C}$ for $16 \mathrm{~h}$ in darkness. Hairy roots obtained after inoculations with wild-type $A$. rhizogenes without a binary vector or with A. rhizogenes carrying unmodified pCAMBIA1381Z were used as controls. GUS activity was examined in newly emerged hairy roots 7 days after subculturing. GUS activity was examined at 7, 14, 21 and 90 dpi (days post infection). The numbers of analysed hairy roots derived from ITEs for each time point are shown in Table S3. At least three independent ITS were used for the experiment where each ITS was represented by number of clones on separate plates and one of these clones (usually three roots containing lateral roots per plate) was used for each time point. The analysis of uninfected and infected ITEs was repeated 3-5 times.

\section{RNA isolation and RT-PCR}

Total RNA was isolated according to method of Chomczynski and Sacchi (2006) from $100 \mathrm{mg}$ of $0.5 \mathrm{~mm}$-long root-tip segments containing apical meristems, roots without meristems collected from a minimum of five 14-day-old tomato plants and root 
Table 1 Characteristics of the isolated promoter regions

\begin{tabular}{lcccl}
\hline Gene & Acc. no. $^{\text {a }}$ & $\begin{array}{l}\text { Length of } \\
\text { promoter } \\
\text { sequence } \\
(\mathrm{bp})^{\mathrm{b}}\end{array}$ & $\begin{array}{l}\text { Length } \\
\text { of } 5^{\prime} \\
\text { UTR } \\
\text { (bp) }\end{array}$ & $\begin{array}{l}\text { Putative } \\
\text { positions } \\
\text { of TATA- } \\
\text { box }^{\mathrm{c}}\end{array}$ \\
\hline CYP97A29 & HE795780 & 1,764 & 131 & -37 \\
DFR & HE795781 & 988 & 82 & -171 \\
FLS & HE795779 & 1,652 & 28 & $-94,-110$ \\
NIK & HE795778 & 1,058 & 187 & -80 \\
PMEI & HE795782 & 1,329 & 114 & $-28,-30$ \\
\hline
\end{tabular}

${ }^{a}$ EMBL nucleotide sequence database

b From the $5^{\prime}$ end of the obtained promoters to the ATG start codons

${ }^{c}$ Positions relative to $5^{\prime}$ end of $5^{\prime}$ UTR

segments containing syncytia at $14 \mathrm{dpi}$. Prior to RTPCR, the RNA preparations $(15 \mu \mathrm{g})$ were treated with RNase-free DNase I (Fermentas) to remove any genomic DNA contamination. First-strand cDNA was synthesized from $0.2 \mu \mathrm{g}$ of DNase-treated RNA using a RevertAid ${ }^{\mathrm{TM}}$ First Strand cDNA Synthesis Kit (Fermentas). For RT-PCR, $1 \mu \mathrm{l}$ of the cDNA preparations was used in each $20 \mu \mathrm{l}$ reaction with genespecific primers. The primer sequences and annealing temperatures are listed in Table S4. The optimal number of PCR cycles was determined for each of the primer pairs and all amplifications were carried out using 29 cycles. A fragment of the constitutively expressed tomato UBI3 gene (Hoffman et al. 1991) was amplified in control PCRs. As template for a DNA control, $0.2 \mu \mathrm{g}$ of DNase-treated RNA were used.

\section{Results}

Cloning and characterization of promoter regions

In order to characterize the regulation of the five selected tomato genes more precisely, the upstream regions of the CYP97A29, DFR, FLS, NIK, and PMEI genes were amplified by nested PCR, cloned and sequenced. The length of the obtained promoter fragments and $5^{\prime}$ UTR regions, and the putative TATA-box positions are shown in Table 1. The sequences upstream of the start codon were screened for cis regulatory elements using the PLACE algorithm. Sequence motifs related to pathogen, growth regulator and abiotic stress responses constituted about $22 \%$ (19.5-29\%) of all identified cis elements. The identified putative pathogen response cis regulatory elements are presented in Table S5.

Establishment of hairy root cultures

To examine the specificity of the analysed promoters during nematode infection, the hairy root system was used. Cotyledon explants (Fig. S1a) appeared to be more suitable than hypocotyl explants for the production of tomato hairy roots, giving greater numbers of

Table 2 GUS activity produced by the analysed promoter regions in tomato and potato hairy roots

\begin{tabular}{|c|c|c|c|c|}
\hline $\begin{array}{l}\text { Gene } \\
\text { name }\end{array}$ & Location of GUS activity in tomato & $\begin{array}{l}\text { Number of } \\
\text { analysed } \\
\text { ITEs }\end{array}$ & Location of GUS activity in potato & $\begin{array}{l}\text { Number of } \\
\text { analysed } \\
\text { ITEs }\end{array}$ \\
\hline СYР97А29 & $\begin{array}{l}\text { In some young root primordia, root } \\
\text { elongation and/or differentiation zones } \\
\text { and/or stele of CRP }\end{array}$ & 4 & Root elongation zone or CRP or whole roots & 3 \\
\hline$D F R$ & $\begin{array}{l}\text { CRP, root elongation zone, or root } \\
\text { elongation and differentiation zones }\end{array}$ & 7 & $\begin{array}{l}\text { In most cases, whole roots, but sometimes } \\
\text { without meristems, or only in root elongation } \\
\text { zone and/or its meristems } \mathrm{s}^{\mathrm{a}}\end{array}$ & 7 \\
\hline$F L S$ & Stele of CRP or root elongation zone & 5 & Whole roots or $\mathrm{CRP}^{\mathrm{a}}$ & 4 \\
\hline$N I K$ & $\begin{array}{l}\text { Stele, root-tip meristems and root } \\
\text { primordia }\end{array}$ & 3 & Whole roots ${ }^{\mathrm{a}}$ & 3 \\
\hline$P M E I$ & $\begin{array}{l}\text { Root meristems, primordia, or } \\
\text { elongation zone, or stele of CRP, root- } \\
\text { hairs }\end{array}$ & 7 & $\begin{array}{l}\text { Whole roots or root tips (meristems, elongation } \\
\text { and differentiation zones), primordia }\end{array}$ & 9 \\
\hline
\end{tabular}

$C R P$ central root part, i.e. root fragment without the root base and meristem

${ }^{a}$ GUS activity was lower than in tomato roots 


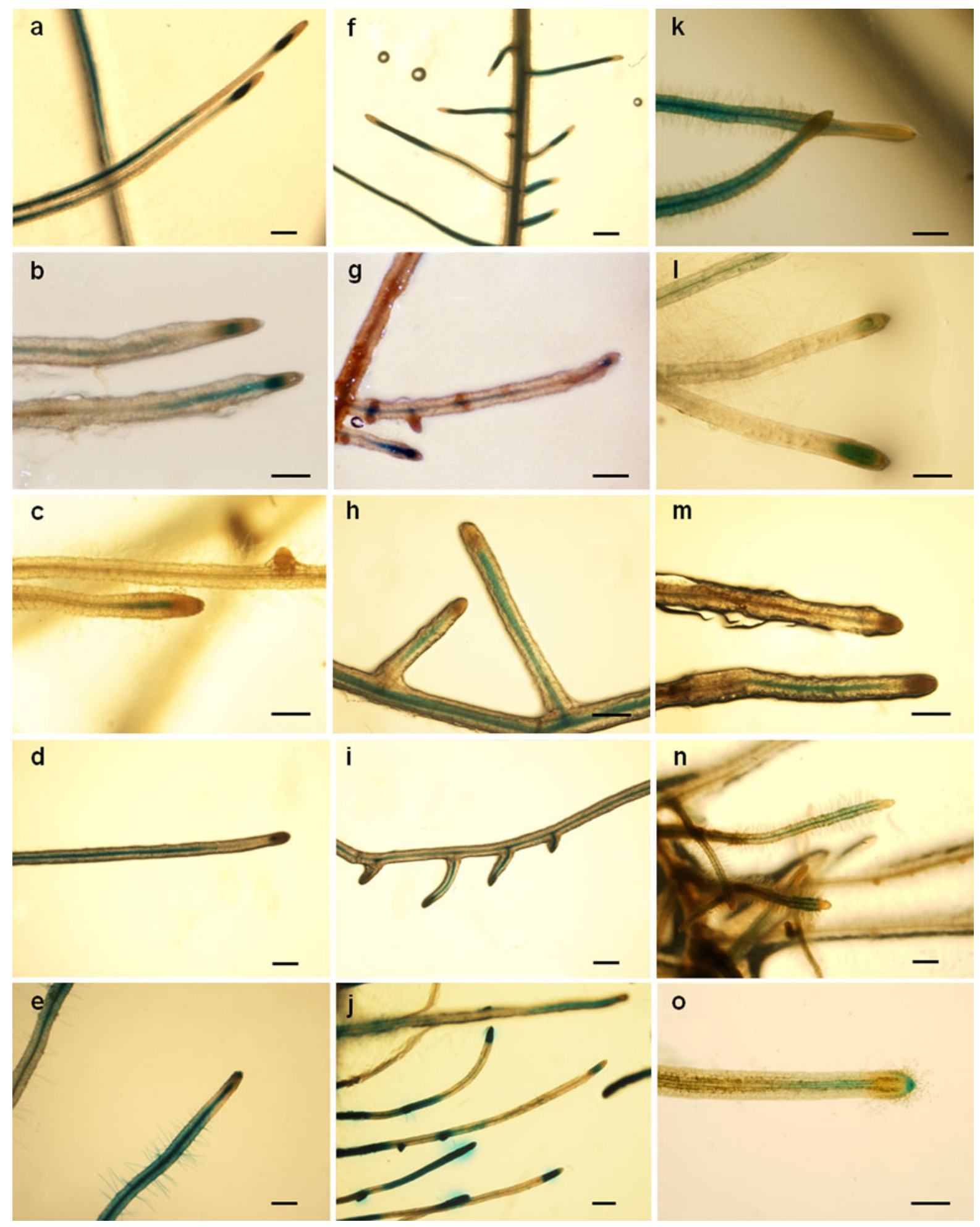

Fig. 1 Activity of promoters in uninoculated tomato (a-j) and potato (k-o) hairy roots. GUS staining of transgenic lines carrying the promoters of the genes $C Y P 97 A 29(\mathbf{a}, \mathbf{f}$ and $\mathbf{k}), D F R$ (b, $\mathbf{g}$ and $\mathbf{l}), F L S(\mathbf{c}, \mathbf{h}$ and $\mathbf{m}), N I K(\mathbf{d}, \mathbf{i}$ and $\mathbf{n})$ and $P M E I(\mathbf{e}, \mathbf{j}$ and o). Details in Table 2. Scale bars $0.5 \mathrm{~mm}$ 
Fig. 2 Activity of CYP97A29, DFR, FLS, NIK and $P M E I$ promoters in G. rostochiensis NFS induced in tomato (a-e) and potato $(\mathbf{f}-\mathbf{j})$ hairy roots. CYP97A29 at 21 (a) and 7 (f) dpi. DFR at 14 (b) and 21 (g) dpi. FLS at $21 \mathrm{dpi}$ (c and h). NIK at 14 (d) and 90 (i) dpi. PMEI at 21 dpi (e and j). Numbers of analysed hairy roots are shown in Table S3. Syncytium (star), nematode (arrow). Scale bars $0.5 \mathrm{~mm}$
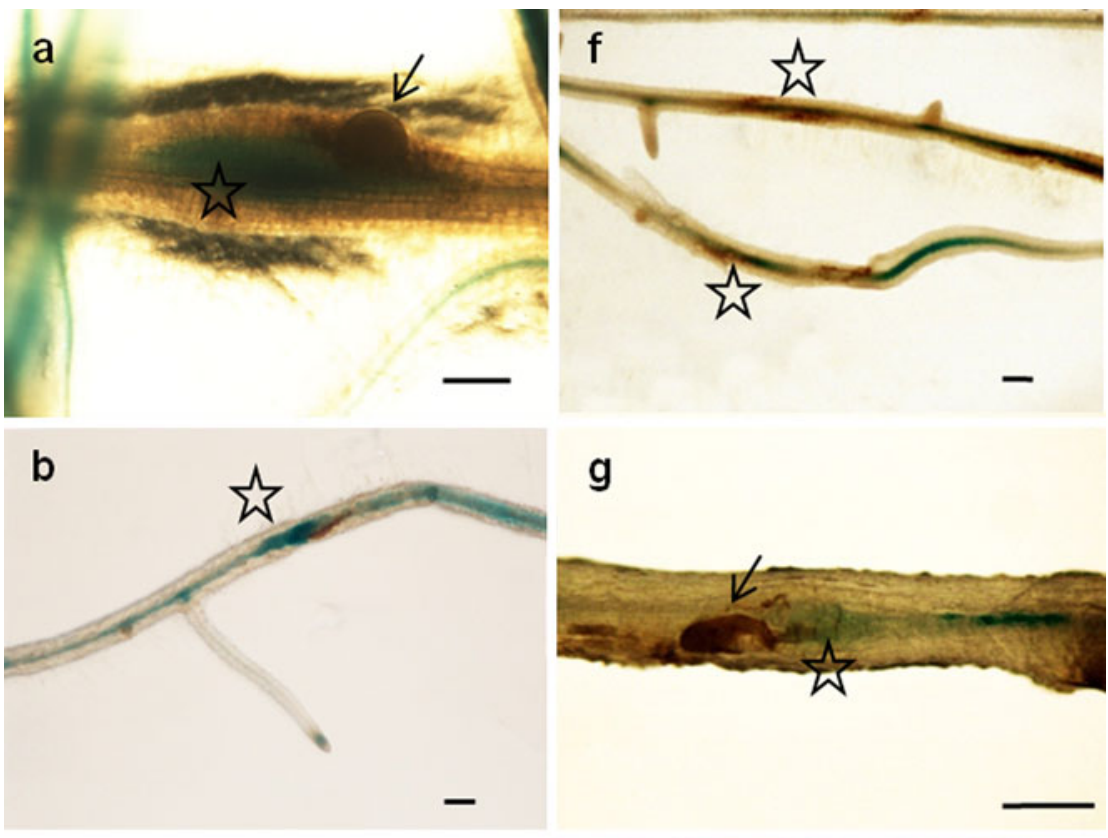

g
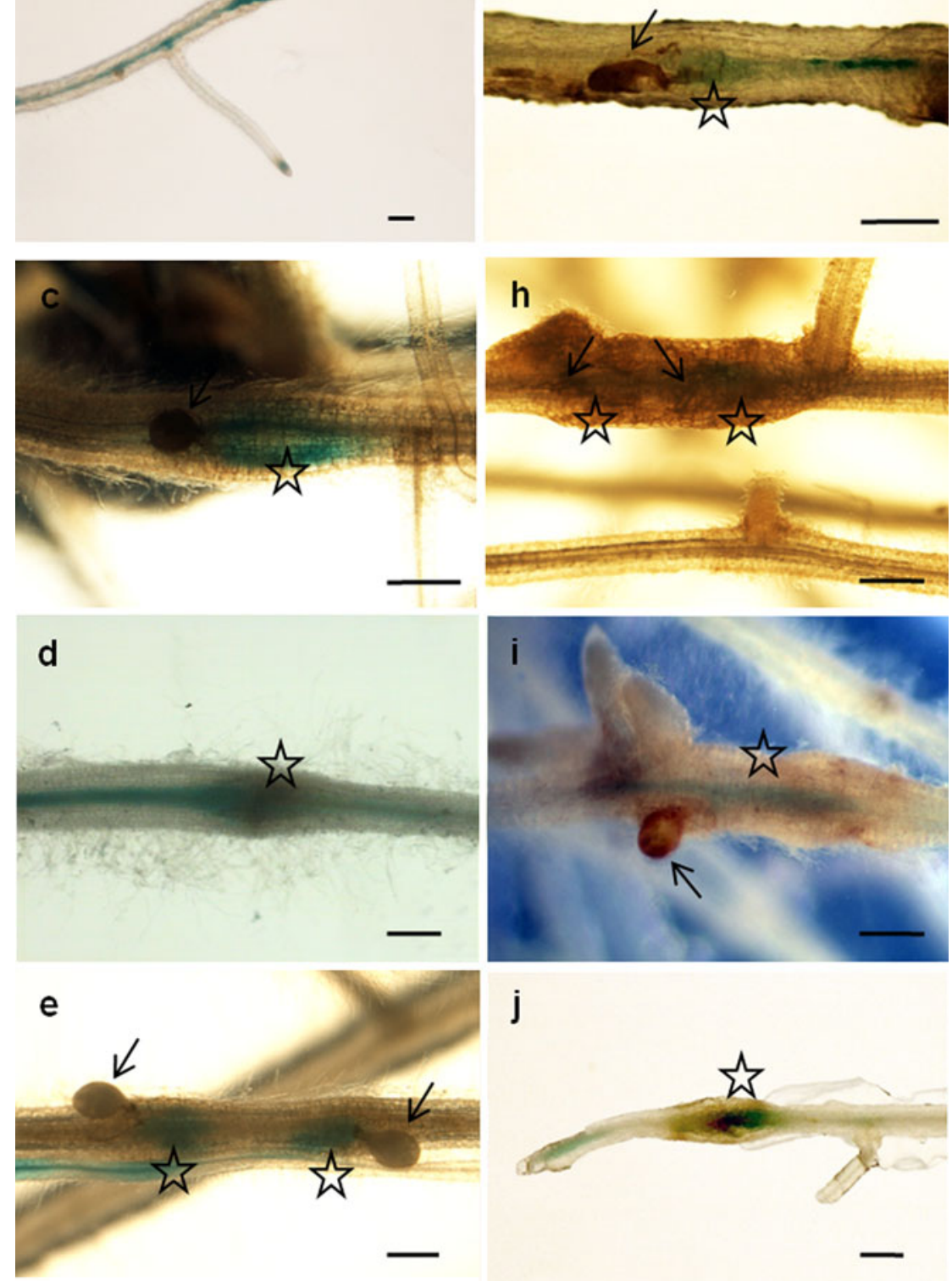
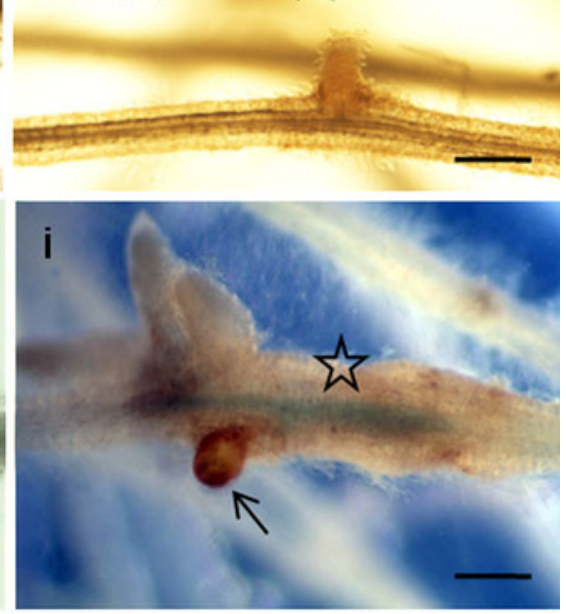

j

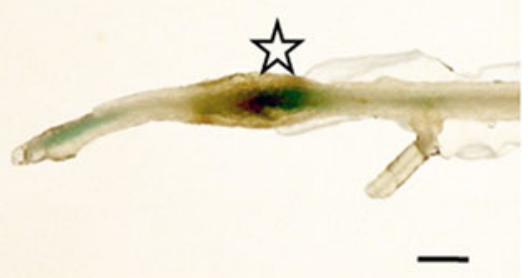




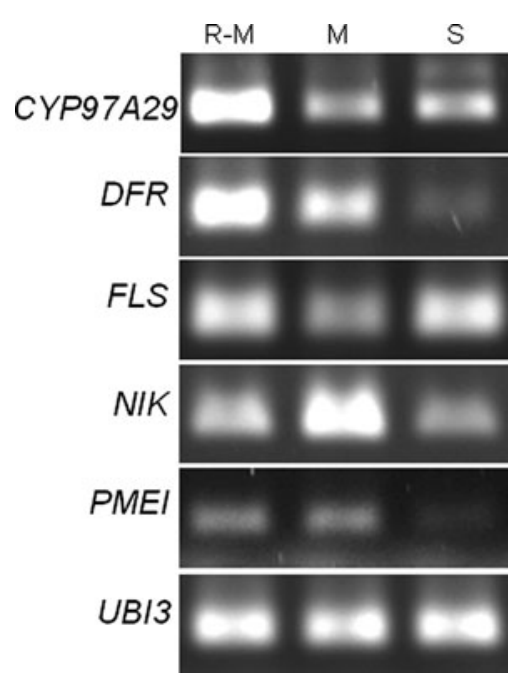

Fig. 3 Semi-quantitative RT-PCR analysis of CYP97A29, DFR, FLS, NIK and PMEI transcript levels in G. rostochiensis-infected and uninfected tomato roots. The tomato $U B I 3$ gene was used as a control. $M$ root-tip meristems of uninfected roots. $R-M$ uninfected roots without root-tip meristems. $S$ root segments with syncytia at $14 \mathrm{dpi}$

transformed roots and a higher root growth rate. In the case of potato (Fig. S1b), stem explants were more efficient than leaf explants for the production of hairy roots.

Activation of promoter regions in uninfected hairy roots

Depending on the analysed promoter, GUS activity was examined in hairy roots obtained from between 3 and 9 ITE (Table 2). Hairy roots obtained by transformation with wild-type A. rhizogenes or A. rhizogenes carrying unmodified vector pCAMBIA1381Z(k) served as controls.

No GUS activity was observed in any control hairy root line (data not shown). GUS activity was detected in uninfected tomato and potato hairy roots obtained using all of the promoter fusions (Fig. 1). However, none of the analysed lines showed any wound-related GUS activity. The patterns of activity appeared to be similar for all of the analysed promoters. GUS staining was observed in meristems, lateral root primordia, the epidermis and stele (along the whole root or only in sectors). In the oldest parts of hairy roots, no GUS activity was usually observed where lateral roots emerged. GUS activity was detected in secondary and tertiary lateral roots. Details are presented in Table 2.
Most, but not all of the hairy roots cultured under antibiotic selection showed GUS activity.

Changes in promoter activity in hairy roots following infection with $G$. rostochiensis

GUS activity was examined in hairy roots 7, 14, 21 and 90 days after inoculation with juveniles of G. rostochiensis. After infection, the growth of syncytia as well as the development of nematodes was observed (Fig. S2). No GUS activity was found in control hairy roots obtained by transformation with wild-type A. rhizogenes or a strain carrying unmodified pCAMBIA1381Z(k), following G. rostochiensis infection.

Necrosis of root tissues was observed during the migration of juveniles, but no GUS activity was detected in cells located next to these necrotic areas at 7 dpi. Where a juvenile induced a NFS, GUS activity was observed at $7 \mathrm{dpi}$ in syncytia, but only in hairy roots containing the NIK or CYP97A29 promoter constructs, in tomato and potato, respectively (Fig. 2f). However, the regulatory regions of all the analysed genes produced GUS activity in older syncytia (at 14-21 dpi) in both plant species (Fig. 2). Moreover, the promoter activities were not changed in other parts of the roots after nematode infection. At 90 dpi, GUS activity in syncytia was detected only in potato hairy roots carrying the NIK promoter construct (Fig. 2i).

It was noted that GUS activity was sometimes absent from syncytia in different hairy root lines infected with $G$. rostochiensis. To examine this phenomenon, the GUS staining of syncytia in tomato hairy roots was evaluated at $21 \mathrm{dpi}$ (Table S6). On average, about $40 \%$ of the developed syncytia showed no blue staining and there was no relationship between the lack of GUS activity and the promoter construct used or the sex of the attached nematode.

Expression profiles of CYP97A29, DFR, FLS, NIK and $P M E I$ genes

Using the cDNA-AFLP method, Swiecicka et al. (2009) found that five genes analysed in the present study were up-regulated in G. rostochiensis-infected roots from 1 to $14 \mathrm{dpi}$, but the highest transcript accumulation was observed at 1 and/or 3 dpi. To verify this finding and to confirm our results obtained using promoter-gusA fusions, the expression of the 
CYP97A29, DFR, FLS, NIK and PMEI genes in infected and uninfected tomato plants was studied by semi-quantitative RT-PCR. RNA was isolated from tomato seedling root-tip segments containing meristems $(\mathrm{M})$, roots without root-tip meristems $(\mathrm{R}-\mathrm{M})$ and (because we did not observe GUS activity with most of the analysed promoters at $7 \mathrm{dpi}$ ) G. rostochiensisinfected root segments containing syncytia at $14 \mathrm{dpi}$ (S). Different levels of expression of all the analysed genes were detected in roots as well as in syncytia. An increased level of transcript in meristems in comparison with the rest of the root (R-M) was observed only for the NIK gene (Fig. 3). In the case of the CYP97A29, DFR and FLS genes, the expression in root meristems was lower than in R-M. Transcript levels of the analysed genes varied in syncytia at 14 dpi. The level of the PMEI and DFR mRNAs was lower in syncytia than in other root parts, while expression of the CYP97A29 and NIK genes was moderate and comparable with that observed in the $\mathrm{M}$ and $\mathrm{R}-\mathrm{M}$ samples, respectively. The highest transcript abundance in syncytia was observed for the $F L S$ gene and this was similar to its level in R-M samples.

\section{Discussion}

The molecular mechanisms controlling changes occurring during the development of a NFS from a single initial cell into a multicellular syncytium are largely uncharacterized. There is a particular dearth of knowledge concerning the promoter cis regulatory elements responsible for the control of host gene expression during plant-nematode interactions. In this study we have examined the pattern of transcriptional regulation of five tomato genes selected from a panel of genes showing altered expression patterns during nematode parasitism (Swiecicka et al. 2009).

The activity of the promoter regions of the five selected genes (CYP97A29, DFR, FLS, NIK and $P M E I)$ was analysed in tomato and potato hairy roots before and after infection with juveniles of G. rostochiensis. GUS activity was detected in different parts of the hairy roots depending on the gene promoter, but in all cases it was observed in or close to NFS. This finding and the results of the RT-PCR analysis clearly indicate that the host genes exploited by the nematode in NFS development are involved in common basic processes occurring in root tissues or in other plant organs.

The promoter most often used for the production of transgenic plants is that of the cauliflower mosaic virus $(C a M V) 35 S$ gene. In transgenic tobacco roots, the full $35 \mathrm{~S}$ promoter was activated in $90 \%$ of NFS induced by $M$. incognita and in $27 \%$ of NFS induced by juveniles of Globodera tabacum subsp. tabacum (Bertioli et al. 1999). Urwin et al. (1997) showed that the $35 \mathrm{~S}$ promoter was activated in the gall tissue surrounding the feeding site of $M$. incognita. Similarly, Goverse et al. (1998) found that expression of a GFP reporter gene fused to the $35 \mathrm{~S}$ promoter was strongly upregulated in young feeding cells during infection by G. rostochiensis. However, these findings are not corroborated by results obtained in Arabidopsis, where 35S-driven GUS activity was down-regulated in NFS induced by $H$. schachtii (Goddijn et al. 1993; Sijmons et al. 1994). Moreover, Goddijn et al. (1993) also showed that the 35S promoter and other constitutive promoters of genes such as bacterial nopaline synthase, rooting loci (rol) and T-cyt, plant phenylalanine ammonia-lyase I and others were downregulated in syncytia. Besides this discrepancy, constitutive promoters are not a good choice to drive the expression of resistance or other genes encoding nematode toxic compounds, because rather high root or syncytium specificity is essential.

Promoter tagging is one method that has been employed for the identification of NFS-specific promoters (Barthels et al. 1997; Favery et al. 2004). Barthels et al. (1997) analysed six tags that were differentially activated during the development of the NFS, and three of these were reintroduced as promoter-gusA fusions and analysed in detail. Besides the NFS, GUS activity was also detected in the roots, shoots and leaf vascular tissue of transformed Arabidopsis plants. Another approach used to identify NFS-specific promoters is the detailed analysis of regulatory sequences of genes identified as being differentially expressed in these structures.

The expression patterns of genes and the activities of most gene promoters analysed to date, have not been restricted to NFS or roots, e.g. RPE (Favery et al. 1998), LEMMI9 (Escobar et al. 1999), AtFH6 (Favery et al. 2004), or AtAMT1;2, LBD41, ADF3 and LTP (Fuller et al. 2007), and NtCel7 (Wang et al. 2007). The RPE gene, encoding D-ribulose-5-phosphate 3 -epimerase, was found to be essential for the early 
steps of NFS formation induced by $M$. incognita and later induced by both root-knot and cyst nematodes, and to a lower level in syncytia. During root development, $R P E$ is normally expressed in the meristems and lateral root primordia (Favery et al. 1998). The promoters of the ADF3 and LTP genes, which are activated in different parts of uninfected Arabidopsis roots, showed activity in the galls of M. incognita, and during the intial steps of $H$. schachtii parasitism, but not when the female became saccate (Fuller et al. 2007). Besides NFS induced by $M$. incognita, the promoter of the LEMMI9 gene, coding for a Lea-like protein, is strongly induced in roots and green tomato fruits (Van der Eycken et al. 1996). Escobar et al. (1999) located a 12-bp repeat that is possibly involved in the formation of DNA-protein complexes in the LEMMI9 promoter, which might be related to transcriptional activation of the LEMMI9 gene in the giant cells. Formin, encoded by the AtFH6 gene, is required for organization of the actin cytoskeleton, and its promoter was found to be up-regulated in developing giant cells (Favery et al. 2004). GUS activity related to this promoter was observed in differentiating vascular cylinder cells just above the root-tip meristem, in the vascular tissue of the lateral root primordia and in the newly emerged lateral roots. In young Arabidopsis seedlings, low levels of AtFH6 promoter activity were also detected in the vascular bundles of leaves and in the stipules (Favery et al. 2004).

Promoter deletion analysis has been used to define regulatory fragments that show specific activation. TobRB7, encoding a putative water channel (Conkling et al. 1990) that is expressed in root meristematic and immature vascular cylinder cells, was up-regulated in tobacco giant cells induced by $M$. incognita (Yamamoto et al. 1991; Opperman et al. 1994). Deletion of the TobRB7 promoter sequence resulted in restriction of its activity only to NFS of Meloidogyne, but not of G. tabacum in tobacco (Yamamoto et al. 1991). The promoter of the pyk20 gene from A. thaliana has also been analysed in detail (Puzio et al. 2000), and a regulatory region located between -277 and $-1 \mathrm{bp}$ relative to the start codon, encompassing the $5^{\prime}$ UTR, was found to be necessary to enhance the level of GUS expression in NFS. GUS activity was produced by all analysed pyk20 promoter deletion clones in other organs of Arabidiopsis seedlings (Puzio et al. 2000). Analysis of the promoter of the $H S 1^{\text {pro-1 }}$ resistance gene from sugar beet identified cis elements responsible for NFS-specific gene expression located within the sequence between -255 and $+247 \mathrm{bp}$ relative to the transcriptional initiation site, whereas an enhancer region, active in sugar beet and A. thaliana, was located between $-1,199$ and $-705 \mathrm{bp}$ (Thurau et al. 2003).

The identification of a specific set of cis regulatory elements activated by different nematode species is a goal that has yet to be achieved. In the present study, the investigated gene promoters exhibited similar patterns of activity in different root tissues and were strongly up-regulated in syncytia induced by G. rostochiensis in tomato and potato roots. The hairy root system employed in this study is a simple and fast tool to test whether promoters are potentially useful for biotechnological applications. However, it is necessary to corroborate any findings by performing further analyses using plants with stably introduced transgenes.

The sequences of the promoters isolated for this study were analysed using bioinformatics tools and some known pathogenesis-related cis regulatory motifs were found. However, the function of these potential regulatory elements has so far only been confirmed for bacterial and fungal pathogens. Among the 29 classes of transcriptional regulators identified in A. thaliana, members of only three appear to function in the pathogen response: AP2/ERF (APETALA2/ ETHYLENE-RESPONSIVE ELEMENT), WRKY and MYB (Riechmann 2002). The AP2/ERF and WRKY families are plant-specific. Some of them, like the W1 and W2-box [WRKY, (T)TGAC(C/T)], GCClike (AP2/ERF, AGCCGCC), JERE (AP2/ERF, AGACCGCC) and S-box (AP2/ERF, AGCCACC) factors have been well described (Gurr and Rushton 2005). In Arabidopsis, there are 72 expressed WRKY genes that encode crucial regulators of the defence transcriptome and plant pathogen resistance (Eulgem and Somssich 2007). In many plant-pathogen models it has been demonstrated that WRKY transcription factors may function as positive or negative regulators of the plant defence network (Eulgem and Somssich 2007; Pandey and Somssich 2009). Recently, Grunewald et al. (2008) showed that AtWRKY23 is involved in the development of syncytia induced by $H$. schachtii. WRKY23 was shown to be strongly up-regulated in young syncytia, while its expression decreased during their further development. Activation of the WRKY23 promoter is related to auxin accumulation and 
WRKY23 acts downstream of the primary auxin response. Two paralogous genes of tomato, SlWRKY72a and $b$, were found to be up-regulated during the resistance response against root-knot nematode and potato aphids mediated by the $\mathrm{Mi}-1$ gene (Bhattarai et al. 2010). Similarly, the Arabidopsis orthologue AtWRKY72 was also required for full basal defence against this nematode (Bhattarai et al. 2010). These results demonstrate that WRKY transcription factors are not only induced by bacterial or fungal pathogens, but also by nematodes. In the present study, we have identified putative $W$-box regulatory elements, that specifically bind WRKY proteins, in the promoters of each of the 5 genes whose expression is up-regulated by nematodes. The use of promoter deletion analysis and complementary methods is required to examine the role of the W-box and other putative elements in regulating the expression of these genes.

Solanum tuberosum is a close relative of Solanum lycopersicoides (Bohs and Olmstead 1997) and both are good hosts for $G$. rostochiensis. The similar activity patterns of the analysed promoters in syncytia induced in tomato and potato roots observed in the present study suggest that the manner of their regulation is the same in both species, and that it should be possible to use these promoters to control expression of anti-nematode products in related plants.

In conclusion, we have demonstrated that the promoters of 5 tomato genes (CYP97A29, DFR, FLS, $N I K$ and $P M E I)$ are active in syncytia induced by G. rostochiensis infection in the roots of both tomato and potato. These promoters may be used to drive the expression of nematocidal products in transgenic plants, but detailed functional characterization of their regulatory sequences, including deletion analysis, is required.

Acknowledgments We are indebted to Jacek Hennig and Magdalena Krzymowska (Laboratory of Plant Pathogenesis, Institute of Biochemistry and Biophysics, PAS, Poland) for their help and valuable discussions. Cysts of G. rostochiensis were kindly provided by Aska Goverse (Laboratory of Nematology, Wageningen University and Research Centre, The Netherlands). This work was supported by a grant from the Polish Ministry of Science and Higher Education, no. 2P06A 03230.

Open Access This article is distributed under the terms of the Creative Commons Attribution License which permits any use, distribution, and reproduction in any medium, provided the original author(s) and the source are credited.

\section{References}

Abad P, Williamson WM (2010) Plant nematode interaction: a sophisticated dialogue. Adv Bot Res 53:147-192

Ammati M, Thomason IJ, Roberts PA (1985) Screening Lycopersicon spp. for new genes imparting resistance to rootknot nematodes (Meloidogyne spp.). Plant Dis 69:112-115

Ammati M, Thomason IJ, McKinney HE (1986) Retention of resistance to Meloidogyne incognita in Lycopersicon genotypes at high soil temperature. J Nematol 18:491-495

An SH, Sohn KH, Choi HW, Hwang IS, Lee SC, Hwang BK (2008) Pepper pectin methylesterase inhibitor protein CaPMEII is required for antifungal activity, basal disease resistance and abiotic stress tolerance. Planta 228:61-78

Bakker E, Achenbach U, Bakker J, van Vliet J, Peleman J, Segers B, van der Heijden S, van der Linde P, Graveland R, Hutten R, van Eck H, Coppoolse E, van der Vossen E, Bakker J, Goverse A (2004) A high-resolution map of the H1 locus harbouring resistance to the potato cyst nematode Globodera rostochiensis. Theor Appl Genet 109:146-152

Barthels N, Van Der Lee FM, Klap J, Goddijn OJ, Karimi M, Puzio P, Grundler FM, Ohl SA, Lindsey K, Robertson L, Robertson WM, Van Montagu M, Gheysen G, Sijmons PC (1997) Regulatory sequences of Arabidopsis drive reporter gene expression in nematode feeding structures. Plant Cell 9:2119-2134

Bertioli DJ, Smoker M, Burrows PR (1999) Nematode-responsive activity of the cauliflower mosaic virus $35 \mathrm{~S}$ promoter and its subdomains. Mol Plant Microbe Interact 12: 189-196

Bhattarai KK, Atamian HS, Kaloshian I, Eulgem T (2010) WRKY72-type transcription factors contribute to basal immunity in tomato and Arabidopsis as well as genefor-gene resistance mediated by the tomato R gene $M i-1$. Plant J 63:229-240

Bohs L, Olmstead RG (1997) Phylogenetic relationships in Solanum (Solanaceae) based on $n d h F$ sequences. Syst Bot 22:5-17

Cai D, Kleine M, Kifle S, Harloff HJ, Sandal NN, Marcker KA, Klein-Lankhorst RM, Salentijn EM, Lange W, Stiekema WJ, Wyss U, Grundler FM, Jung C (1997) Positional cloning of a gene for nematode resistance in sugar beet. Science 275:832-834

Chomczynski P, Sacchi N (2006) The single-step method of RNA isolation by acid guanidiniumthiocyanate-phenolchloroform extraction: twenty-something years on. Nat Protoc 1:581-585

Conkling MA, Cheng CL, Yamamoto YT, Goodman HM (1990) Isolation of transcriptionally regulated root-specific genes from tobacco. Plant Physiol 93:1203-1211

Dropkin VH (1969) The necrotic reaction of tomatoes and other hosts resistant to Meloidogyne: reversal by temperature. Phytopathology 59:1632-1637

Ernst K, Kumar A, Kriseleit D, Kloos DU, Phillips MS, Ganal MW (2002) The broad-spectrum potato cyst nematode resistance gene (Hero) from tomato is the only member of a large gene family of NBS-LRR genes with an unusual amino acid repeat in the LRR region. Plant J 31:127-136

Escobar C, De Meutter J, Aristizabal FA, Sanz-Alferez S, Del Campo FF, Bartels N, Van Der Eycken W, Seurinck J, Van Montagu M, Gheysen G, Fenoll C (1999) Isolation of the 
LEMMI9 gene and promoter analysis during a compatible plant-nematode interaction. Mol Plant Microbe Interact 12:440-449

Eulgem T, Somssich IE (2007) Networks of WRKY transcription factors in defense signaling. Cur Opin Plant Biol 10:366-371

Favery B, Lecomte P, Gil N, Bechtold N, Bouchez D, Dalmasso A, Abad P (1998) RPE, a plant gene involved in early developmental steps of nematode feeding cells. EMBO J 17:6799-6811

Favery B, Chelysheva LA, Lebris M, Jammes F, Marmagne A, de Almeida-Engler J, Lecomte P, Vaury C, Arkowitz RA, Abad P (2004) Arabidopsis formin AtFH6 is a plasma membrane-associated protein upregulated in giant cells induced by parasitic nematodes. Plant Cell 16:2529-2540

Fuller VL, Lilley CJ, Atkinson HJ, Urwin PE (2007) Differential gene expression in Arabidopsis following infection by plant-parasitic nematodes Meloidogyne incognita and Heterodera schachtii. Mol Plant Pathol 8:595-609

Gal TZ, Aussenberg ER, Burdman S, Kapulnik Y, Koltai H (2006) Expression of a plant expansion is involved in the establishment of root knot nematode parasitism in tomato. Planta 224:155-162

Giovane A, Servillo L, Balestrieri C, Raiola A, D'Avino R, Tamburrini M, Ciardiello MA, Camardella L (2004) Pectin methylesterase inhibitor. Biochim Biophys Acta 1696: 245-252

Goddijn OJM, Lindsey K, van der Lee FM, Klap JC, Sijmons PC (1993) Differential gene expression in nematode-induced feeding structures of transgenic plants harbouring promoter-gusA fusion constructs. Plant J 4:863-873

Gommers FJ, Bakker J (1993) Biotechnology in nematology. In: Zadoks JC (ed) Modern crop protection: developments and perspectives. Wageningen Press, Wageningen

Goverse A, Biesheuvel J, Wijers G-J, Gommers FJ, Bakker J, Schots A, Helder J (1998) In planta monitoring of the activity of two constitutive promoters, CaMV $35 \mathrm{~S}$ and TR2', in developing feeding cells induced by Globodera rostochiensis using green fluorescent protein in combination with confocal laser scanning microscopy. Physiol Mol Plant Pathol 52:275-284

Goverse A, Overmars H, Engelbertink J, Schots A, Bakker J, Helder J (2000) Both induction and morphogenesis of cyst nematode feeding cells are mediated by auxin. Mol Plant Microbe Interact 13:1121-1129

Grunewald W, Karimi M, Wieczorek K, Van de Cappelle E, Wischnitzki E, Grundler F, Inzé D, Beeckman T, Gheysen G (2008) A role for AtWRKY23 in feeding site establishment of plant-parasitic nematodes. Plant Physiol 148:358-368

Gurr SJ, Rushton PJ (2005) Engineering plants with increased disease resistance: how are we going to express it? Trends Biotechnol 23:283-290

Hadisoeganda WW, Sasser JN (1982) Resistance of tomato, bean, southern pea, and garden pea cultivars to root-knot nematodes based on host suitability. Plant Dis 66:145-150

Haegeman A, Mantelin S, Jones JT, Gheysen G (2012) Functional roles of effectors of plant-parasitic nematodes. Gene 492:19-31

Hansen E, Harper G, Mcpherson MJ, Atkinson HJ (1996) Differential expression patterns of the wound-inducible transgene wun-1-uidA in potato roots following infection with either cyst or root-knot nematodes. Physiol Mol Plant Pathol 48:161-170

Hewezi T, Howe P, Maier TR, Hussey RS, Mitchum MG, Davis EL, Baum TJ (2008) Cellulose binding protein from the parasitic nematode Heterodera schachtii interacts with Arabidopsis pectin methylesterase: cooperative cell wall modification during parasitism. Plant Cell 20:3080-3093

Higo K, Ugawa Y, Iwamoto M, Korenaga T (1999) Plant cisacting regulatory DNA elements (PLACE) database. Nucleic Acids Res 27:297-300

Hoffman NE, Ko K, Milkowski D, Pichersky E (1991) Isolation and characterization of tomato cDNA and genomic clones encoding the ubiquitin gene ubi3. Plant Mol Biol 17: 1189-1201

Huang G, Allen R, Davis EL, Baum TJ, Hussey RS (2006) Engineering broad root-knot resistance in transgenic plants by RNAi silencing of a conserved and essential root-knot nematode parasitism gene. Proc Natl Acad Sci USA 103:14302-14306

Hutangura P, Mathesius U, Jones MGK, Rolfe BG (1999) Auxin induction is a trigger for root gall formation caused by rootknot nematodes in white clover and is associated with the activation of the flavonoid pathway. Aust J Plant Physiol 26:221-231

Hwang IS, Hwang BK (2010) Role of the pepper cytochrome P450 gene CaCYP450A in defense responses against microbial pathogens. Planta 232:1409-1421

Hwang CF, Bhakta AV, Truesdell GM, Pudlo WM, Williamson VM (2000) Evidence for a role of the $\mathrm{N}$ terminus and leucine-rich repeat region of the $M i$ gene product in regulation of localized cell death. Plant Cell 12:1319-1329

Jefferson RA, Kavanagh TA, Bevan MW (1987) GUS fusions: $\beta$-glucuronidase as a sensitive and versatile gene fusion marker in higher plants. EMBO J 6:3901-3907

Jones JT, Furlanetto C, Phillips MS (2007) The role of flavonoids produced in response to cyst nematode infection of Arabidopsis thaliana. Nematology 9:671-677

Kahn R, Durst F (2000) Function and evolution of plant cytochrome P450. Rec Adv Phytochem 34:151-189

Kaloshian I, Williamson VM, Miyao G, Lawn DA, Westerdahl BB (1996) "Resistance-breaking" nematodes identified in California tomatoes. Calif Agric 50:18-19

Li J, Todd TC, Trick HN (2010a) Rapid in planta evaluation of root expressed transgenes in chimeric soybean plants. Plant Cell Rep 29:113-123

Li X, Zhang JB, Song B, Li HP, Xu HQ, Qu B, Dang FJ, Liao YC (2010b) Resistance to Fusarium head blight and seedling blight in wheat is associated with activation of a cytochrome p450 gene. Phytopathology 100:183-191

Lievens S, Goormachtig S, Herman S, Holsters M (2002) Patterns of pectin methylesterase transcripts in developing stem nodules of Sesbania rostrata. Mol Plant Microbe Interact 15:164-168

Lionetti V, Raiola A, Camardella L, Giovane A, Obel N, Pauly M, Favaron F, Cervone F, Bellincampi D (2007) Overexpression of pectin methylesterase inhibitors in Arabidopsis restricts fungal infection by Botrytis cinerea. Plant Physiol 143:1871-1880

Liu F, Jiang H, Ye S, Chen WP, Liang W, Xu Y, Sun B, Sun J, Wang Q, Cohen JD, Li C (2010) The Arabidopsis P450 
protein CYP82C2 modulates jasmonate-induced root growth inhibition, defense gene expression and indole glucosinolate biosynthesis. Cell Res 20:539-552

Milligan SB, Bodeau J, Yaghoobi J, Kaloshian I, Zabel P, Williamson VM (1998) The root knot nematode resistance gene $M i$ from tomato is a member of the leucine zipper, nucleotide binding, leucine-rich repeat family of plant genes. Plant Cell 10:1307-1319

Murashige T, Skoog F (1962) A revised medium for rapid growth and bioassays with tobacco tissue culture. Physiol Plant 15:473-497

Opperman CH, Taylor CG, Conkling MA (1994) Root-knot nematode-directed expression of a plant root-specific gene. Science 263:221-223

Paal J, Henselewski H, Muth J, Meksem K, Menendez CM, Salamini F, Ballvora A, Gebhardt C (2004) Molecular cloning of the potato Grol-4 gene conferring resistance to pathotype Ro1 of the root cyst nematode Globodera rostochiensis, based on a candidate gene approach. Plant J 38:285-297

Pandey SP, Somssich IE (2009) The role of WRKY transcription factors in plant immunity. Plant Physiol 150:1648-1655

Plovie E, De Buck S, Goeleven E, Tanghe M, Vercauteren I, Gheysen G (2003) Hairy roots to test for transgenic nematode resistance: think twice. Nematology 5:831-841

Puzio PS, Lausen J, Heinen P, Grundler FMW (2000) Promoter analysis of pyk20, a gene from Arabidopsis thaliana. Plant Sci 157:245-255

Riechmann JL (2002) Transcriptional regulation: a genomic overview. Arabidopsis Book 1:e0085

Sijmons PC, Cardol EF, Goddijn OJM (1994) Gene activities in nematode-induced feeding structures. In: Daniels MJ (ed) Advances in molecular genetics of plant-microbe interactions, vol 3. Kluwer, Dordrecht, pp 333-338

Sobczak M, Golinowski W (2011) Cyst nematodes and syncytia. In: Gheysen G, Fenoll C, Jones JT (eds) Genomics and molecular genetics of plant-nematode interactions. Springer, Berlin, pp 61-82

Sobczak M, Avrova A, Jupowicz J, Phillips MS, Ernst K, Kumar A (2005) Characterization of susceptibility and resistance responses to potato cyst nematode (Globodera spp.) infection of tomato lines in the absence and presence of the broad-spectrum nematode resistance Hero gene. Mol Plant Microbe Interact 18:158-168

Stigliani AL, Giorio G, D'Ambrosio C (2011) Characterization of P450 carotenoid $\beta$ - and $\varepsilon$-hydroxylases of tomato and transcriptional regulation of xanthophyll biosynthesis in root, leaf, petal and fruit. Plant Cell Physiol 52:851-865

Swiecicka M, Filipecki M, Lont D, Van Vliet J, Qin L, Goverse A, Bakker J, Helder J (2009) Dynamics in the tomato root transcriptome on infection with the potato cyst nematode Globodera rostochiensis. Mol Plant Pathol 10:487-500

Thurau T, Kifle S, Jung C, Cai D (2003) The promoter of the nematode resistance gene $H s 1^{\text {pro-1 }}$ activates a nematoderesponsive and feeding site specific gene expression in sugar beet (Beta vulgaris L.) and Arabidopsis thaliana. Plant Mol Biol 52:643-660

Urwin PE, Atkinson HJ, Waller DA, McPherson MJ (1995) Engineered oryzacystatin-I expressed in transgenic hairy roots confers resistance to Globodera pallida. Plant $\mathbf{J}$ 8:121-131

Urwin PE, Møller SG, Lilley CJ, McPherson MJ, Atkinson HJ (1997) Continual green-fluorescent protein monitoring of cauliflower mosaic virus $35 \mathrm{~S}$ promoter activity in nematode-induced feeding cells in Arabidopsis thaliana. MPMI 10(3):394-400

Van der Eycken W, de Almeida EnglerJ, Inzé D, Van Montagu M, Gheysen G (1996) A molecular study of root-knot nematode-induced feeding sites. Plant J 9:45-54

Van der Vossen EA, van der Voort JN, Kanyuka K, Bendahmane A, Sandbrink H, Baulcombe DC, Bakker J, Stiekema WJ, Klein-Lankhorst RM (2000) Homologues of a single resistance-gene cluster in potato confer resistance to distinct pathogens: a virus and a nematode. Plant J 23:567-576

Wang X, Replogle A, Davis EL, Mitchum MG (2007) The tobacco $\mathrm{Cel7}$ gene promoter is auxin-responsive and locally induced in nematode feeding sites of heterologous plants. Mol Plant Pathol 8:423-436

Wasson AP, Pellerone FI, Mathesius U (2006) Silencing the flavonoid pathway in Medicago truncatula inhibits root nodule formation and prevents auxin transport regulation by rhizobia. Plant Cell 18:1617-1629

Williamson VM, Hussey RS (1996) Nematode pathogenesis and resistance in plants. Plant Cell 8:1735-1745

Yamamoto YT, Taylor CG, Acedo GN, Cheng CL, Conkling MA (1991) Characterization of cis-acting sequences regulating root-specific gene expression in tobacco. Plant Cell 3:371-382

Yan XN, Sikora RA, Zheng JW (2011) Potential use of cucumber (Cucumis sativus L.) endophytic fungi as seed treatment agents against root-knot nematode Meloidogyne incognita. J Zhejiang Uni Sci B 12:219-225 